\title{
Yoruba Traditions in the Midst of Foreign Influences, A Critical Evaluation
}

\author{
Kola Adekola \\ University of Ibadan, Nigeria \\ kola.adekola@mail.ui.edu.ng \\ kolawole.adekola@gmail.com
}

\begin{abstract}
The Yoruba of South west Nigeria pride themselves as a "nation" with a rich cultural heritage. This jealously guided heritage believed to have been handed down from ancient times has however suffered greatly from modern influences owing to contacts with foreign cultures. This essay highlights the measures to preserve the Yoruba heritage and the militating problems in the light of the unbridled contacts with foreign cultures. The paper also provides evidence to suggest that the Yoruba, just like every other ethnic groups in $\mathrm{Ni}$ geria, could have fashioned their own developmental frameworks but for the imposition of foreign ideas/ideals.
\end{abstract}

\section{Early History of the Yoruba}

Myths regarding the early history of the Yoruba are as diverse as the Yoruba nation itself. However, many of such myths regarded Odùduwà (the quasi-mythical ancestor of the Yoruba) as the progenitor of the race. The belief was that the diverse Yoruba sub-groups one way or the other descended from Odùduwà. The Yoruba town of Ife also holds a pride of place in many of the mythological history.

The origin of the Yoruba kingdoms were considerably more diverse than the Yoruba people and their traditions would like to acknowledge, it is imperative for scholars to exercise caution in the acceptance of the traditions of the origins of Yoruba ruling dynasties as many of the traditions of origin from Ife are open to question or even doubt (Akintoye, 2010:91). Another version of Yoruba tradition of origins as recorded by Samuel Crowther attached the dynastic ancestor of Yoruba to Okanbi who set out from an unspecified certain region, came to a vast expanse of water across which he and his party 
began wading and eventually created a dry land in the middle of that water in Ife (Law, R 1973, 1984).

According to Mabogunje and Cooper (1971) whatever the origin of the Yoruba dynasties, the picture of dispersal from Ife whether as primary or secondary center is now almost universally accepted. This picture is expressed in terms of family genealogy as the movement of individual descendants of Odùduwà (the quasi-mythical ancestor of all the Yoruba) to become the founders of different towns. Traditions of descent from the universal ancestor at Ife were jealously maintained and the prestige of a ruler was depended on his seniority within this quasi-mythical descent system (Mabogunje and Cooper, 1971:5; Law, R.C 1973). From the available historical and archaeological evidences, there was no doubt that Ife was a major early urban center in Yoruba history but hardcore archaeological evidence is yet to be provided to support the thesis that Ife was the source of the Yoruba country. The Yoruba are organized into large subgroups such as Egba, Ekiti, Ijebu, Ijesha, Ibadan, Oyo, Sabe, Igbomina and Popo.

\section{Yoruba Cultural Practices}

The Yoruba have a distinct way of life. This is clearly expressed in their dietary system, socio-economy, political organization, music, religion, moral values, customs and traditions such as celebrations of naming ceremonies, funerals, rites of passage and more importantly in their language.

Yoruba kinship system is perhaps the building block of the society. In Yoruba society, no one can live independently of his kin group. Kinsmen depend on one another for a wide range of assistance for the sustenance of the group (Adekola, 2011). In many Yoruba groups and towns, the lineage ìdílé is a powerful means of social organization. Each ìdílé is a corporate body made up of males and females who traced their common descent and relationship to one another by a series of genealogical steps through the male line to the founder of the idílé who is also regarded as their ancestor. Membership of the lineage was not however strictly defined by birth. Marital connections are important tickets for membership; the rule of exogamy in the lineage made it compulsory for women to marry out of their ìílé while wives are incorporated and assimilated into their husband's ìílé without losing the membership of their ancestral ìílé. Their children belong primarily to the ìílé of their husband. Each ìdílé has its characteristics and distinguishing features (Falola, 2012)

A child born within the kin group is seen as belonging to all, not to the biological parents' alone. Every member of the kin-group has a role to play in the growth, development and nourishment of the child. The child is also expected 
to learn the mores, customs and traditions of the society within the extended family compound. By so doing the core moral values, discipline and the etiquette expected of a Yoruba person is learnt under the watchful eyes of several adult members of the family. Through lineage affinities, youths are guided by the kin-group to understand the custom and traditions of the Yoruba.

As such a child grows; he/she contributes to the development of the family by bearing some of its responsibilities. In short, a lineage has the collective responsibility for the contribution of goods and services, for the marriage and funeral ceremonies of its members and shared in the execution of religious and ancestral ceremonies. It provided for the care of the elders and the indigent and performed mutual labor services during critical periods for the farming circle, for the construction of a house or any other important task undertaken by any of its members. It was within this social relation that most production activities take place in Yoruba land. (Folorunso, 1998:63).

In furtherance of the family lineage success, the lineage is the first form of group farming. In such instances, the male members of farm going age and of a patrilineal descent work together throughout the farming year as a team under the supervision of the eldest. The proceeds go to the patrilineal group.

Till the close of the Nineteen Century, additional sources of labor include the use of pawns (ìwọ fà) and slaves (ẹú). İwọ fà were individuals pledged as security for a loan. An ìwọ fà worked for the creditor until the principal or capital was paid, his services representing the interest on the loan. Though the institution of ìwọ fà was primarily for raising money, there were other reasons for it. A young child could be pawned to subject him to ẹkọ́ita (external training) under people who would have little sympathy and parental consideration for him. It was also a form of training for youths who could be apprenticed to craftsmen for a considerable length of time, or youths offering their services in lieu of school fees. (Falola, 2012)

The ìwọ fà would work for one day in a five-day week and some even worked for half a day during a week. This working arrangement made it possible for a single person to be pawned to three different masters as he could work for the three of them on three different days and spend the off days in his own occupation. The ìọ fà did the work assigned to him by the creditor. A female ìộ fà could be attached to the master's wife to help in domestic duties and her profession.

The adult ìwọ fà returned home after the day's work which usually ends at noon but children could live with the creditor who would be responsible for their lodging and feeding (Falola, 2012:50-51) Slaves were mostly captives from wars and were regarded as properties of their owners. With this huge labor force, it was easy for influential Yoruba men, lineage heads, chiefs and warriors (as in the case of Ibadan and some other towns) to amass enormous 
wealth. Interestingly however, these are re-distributed in form of patrilineal rights and privileges and of course as gifts. (See Adebayo, 1994:390, Falola 2012)

From the foregoing, it is clearly visible that in the pre-colonial Yoruba culture, individualism is not expressed. Invariably, the act of acting alone or that of 'me and the members of my immediate family' is more or less a direct fall -out of the contact with foreign cultures. In such instances, it is everybody for himself. Nobody cares about his fellow human being. The belief is that every human interaction must always be formal and be based on market economy (Adekola, 1995; 13)

\section{Diet}

The Yoruba exploit a wide range of plant sources as food. Most of the plants can be grouped into root tubers, fruits, nuts as well as vegetables. There are also some important trees which are either exploited for their economic values or for their food products which are extracted from them. Some food and tree crops feature prominently in Yoruba culture. These are crops that were grown during the early phase of the Yoruba culture. In other words, these are indigenous crops which were domesticated from their wild form; examples of these are the Negro Yam (Dioscorea cayensis), Dioscorea rotundata, kola tree as well as oil palm (Elaeis guinensis). Till today, these tree and food crops have attained prestigious positions in Yoruba culture. For example, kolanut is widely used in entertaining visitors amongst the Yoruba and it is regarded as the best present a host can offer to show his delight for the presence of such visitors. Other than this, kolanut features prominently in other aspects of Yoruba cultural expression such as divination.

The oil palm on the one hand is regarded as the tree of life. Many products are extracted from Elaeis guinensis -palm oil (epo pupa), kernel (èkùrọ́), palm wine (emu funfun). According to Sowunmi (1999) the oil palm is of immense commercial and domestic value in tropical west and west central African economies. Apart from plant sources, the Yoruba also supplement their diet with meat. Hunting was formerly a predominant occupation amongst the Yoruba (until recently, hunters were accorded much respect). They hunted for small as well as big animals. Hunting implements used initially before the introduction of dane guns were made from roots and fibers which were used as traps for animals. Later, iron implements were used to trap big game animals.

\section{Hunting and Rituals}

Hunting is considered to be a delicate and dangerous occupation; hence there is the constant performance of rituals by hunters to appease the gods for some games, for their own survival during hunting expeditions and also 
for the repose of the soul of a dead colleague. For example, if a hunter kills a mysterious game such as antelope or gazelle, he needs to perform certain rituals especially if he has a wife who is pregnant during such period. It is believed that it is only the ritual that can save the pregnant woman from giving birth to a mysterious child during delivery. The materials for the ritual must include the tail, ear and hair at the back of the animal as well as palm oil. All these are to be put in a broken potsherd and placed at a cross-road.

\section{Food Taboos}

Some groups of people are forbidden from eating certain food items amongst the Yoruba. For example, the eating of snails, twin banana (oggẹdè ibeji) and monkey is forbidden for a pregnant woman. It is believed that if such a woman at any point in time during pregnancy eats snails, she will give birth to an imbecile. This is clearly an attempt by the Yoruba to guard against a situation whereby a woman would develop complications such as insufficient blood flow during delivery. It is believed that during pregnancy, the woman needs blood which can only be derived from the eating of animals that have blood flowing in their veins and since the Yoruba considered snails to be bloodless animals, the imposition of such a sanction on the pregnant woman becomes inevitable.

Just like snails, a pregnant woman is forbidden from eating twin banana (ọgẹde ibeji). The belief is that such a woman can give birth to Siamese twins, a dead child or have difficult labor during delivery. The taboos are not restricted to food alone. For instance, forests are protected as igbó àìọ or igbó ebora these clearly were attempts to restrict movements into the forests and prevent the destruction of their manifold resources. An overview of these taboo show that most of these taboos are observed to promote peace and stability within the environment and among humans.

\section{Other Cultural Indices}

Other common illustrations to espouse Yoruba cultural traditions can be seen in the naming of their children, wedding and funeral rites. The naming of a newborn baby is rooted in the philosophy ilé là ń wò kí a tó sọmo lórúko (one pays attention to circumstances/situations within the lineage before naming a child). In short, the tradition and history of a child's relatives must be taken into consideration when choosing a name. It is also believed that individuals will live out the meanings of their names.

On the issue of marriage, love, trust and purity of the marital bed is expected from the couple to be. A web of intricate relationships which start with courtship (often through alárinà - the intermediary) is expected to culminate 
in a wedding ceremony involving both the families of the bride and that of the bridegroom. Marriage is not considered to be only a union between husband and wife; it is perceived as the union of the families on both sides. Traditions demand that on the day of the wedding, the bride is accompanied to the husband house by different people mostly family members and friends. Shortly on arrival at her new home, she would be prayed for and her legs washed by the eldest wife of the husband's house before being ushered to her new home. The belief is that the washing of her legs has taken away all the bad luck she might have been carrying. It is sacrosanct that on the wedding night she must have sexual intercourse with her husband as both families and friends eagerly await the outcome of the sexual encounter. A piece of plain white cloth is expected to be soaked with blood after the copulation of husband and wife; this is an indication that the wife is a virgin. In short, the onus is on the bride particularly the first wife to be a virgin till her marriage night, anything short of this could have dire consequences such as the re-payment of the bride price or even outright banishment of the bride's family from the community coupled with shame and mockery that could follow such a sacrilege (Adedoyin Adekola, 1995 Personal Communication)

If the bride was "intact," she would be given "virginity money" by her husband just as her parents would receive a pot of wine from the oil palm and a pot from the raffia palm, both filled to the brim and covered with leaves and five yams from the husband as well (Caldwell, J.C et-al,1991)

Among the Yoruba, death is not perceived as the terminal point of life. There is a strong conviction in after life, that is, the dead person particularly if he/she is aged has only joined the ancestors to bless and guide over the living generations. This accounts for the lavish ceremonies that accompany funeral rites especially of those who were aged and also left behind successful children and grand-children. For those who die young but have well-to do children, the Yoruba have a saying kákú lọmọdé kó yẹni sàn ju kí a dàgbà, kí a má ní adire ìrànà meaning it is better to die young and be celebrated than to be aged without a befitting celebration to see one to the world beyond.

In terms of the socio-political organization, the Yoruba political system is highly complicated. At the family level is the baále who is the eldest in the lineage. He controls, disciplines and oversees the affairs of the family units under his patrilineage. The baálé is expected to be a man of wisdom, a privilege conferred on him by age and by the fact that he must have been a close observer/participant in family norms, rules, regulations, rituals and ancestral veneration over the years. The baálé is expected to be fair minded, be able to dispense justice without fair or favor. He holds the wealth/ resources (land, capital and mobilization of labor) of the lineage in trust with a bid to 
ensure that each member of the lineage has his own fair share from the common pool.

At a higher level is the baálè (ruler of a territory). He is expected to be a member of the Ògbóni cult, an association regarded as a union of the City's notables. Though the baálè holds court and performs almost similar role to that of the baále (lineage ruler) but now at a higher level because he oversees a wider area, weighty issues that has to do with life and death, declaration of war, atonement for peace and ritual performances are decided by the Ògbóni cult following the request by the baálẹ. The Ògbóni cult, its activities, membership, do's and don'ts have been extensively described by Leo Frobenius (Frobenious, 1913:167-185)

At the highest level is the Oba regarded as the supreme authority. He is often referred to as kábíyèsí ( $k$ á bi í kò sí) that is, somebody that nobody can query his authority. He rules over towns, kingdoms and empires. For instance, the Alaafin as the ruler of the Old Oyo Empire wielded enormous empire that spread not only over the Yoruba territories but also to Dahomey.

According to Mabogunje and Omer-Cooper (1971) as Oyo grow more powerful, its influence extended beyond the area inhabited by Yoruba speaking peoples. This expansion took place westward into modern Dahomey. There, a cluster of small states all recognizing the seniority of Ardra had grown up and were actively engaged in trade with Europeans at the coast. As early as 1703, an Oyo expedition entered the area to discipline the king of Ardra but it is unlikely that more than a very informal sphere of influence was established (Mabogunje\& Omer-Cooper, 1971:14).

However, in spite of the enormous powers of the Alaafin, a group of Oyo kingmakers Oyomesi are to check the excesses of the Oba. The position of the Bashorun too was highly revered to the extent that prior to the reign of Alaafin Abiodun, about four previous Alaafins were sent to their early graves by Bashorun Gaha, a notorious warlord in Yorubaland. For the Oba, the Aafin (palace) is usually a monumental architecture (Adekola, 1992) built through the skills of the best workmen within the kingdom. Owu, and Old Oyo for instance had massively built monumental palaces (Akintoye, 2010). Recent archaeological investigations by the Department of Archaeology and Anthropology, University of Ibadan in Orile-Owu tend to confirm these historical accounts. It is also important to note that within the palace are a retinue of servants, slaves, and free born performing several roles. Amongst these are the praise singers (arokin oba) who jealously guard the historical genealogy stories of the royal families. 


\section{Discussion and Conclusion}

The introduction of the two major religions to Yoruba land (Islam and Christianity) as well as Colonialism has exerted very profound influences on Yoruba culture. Islam penetrated the Yoruba country through the northern part of Nigeria as early as the $17^{\text {th }}$ century while Christianity was introduced in the $18^{\text {th }}$ century. Colonialism followed immediately in the $19^{\text {th }}$ century, this was established with the conquest of Lagos in 1851.

As the influence of both Islam and Christianity continues to deepen significantly among the Yoruba, the younger generations of Yoruba people tend to adhere more to the fundamentals of the Islamic or Christian faith, thereby distancing themselves from the spiritual ramifications of the indigenous cultures. For instance, in the mission schools, students were taught that a renunciation of the culture of their society-customs, indigenous names, clothing and language was essential to attaining their new status of civilized people (Akintoye, 2010). A direct consequence of the "evangelization exercise" of Islam and Christianity was that by the middle of the $20^{\text {th }}$ century, many Yoruba households were either Muslims or Christians. For instance, in the defunct Ondo state (now Ekiti and Ondo states), the 1921 national census figures stated that $84 \%$ of the population followed the traditional religion as of the year of the census, thirty-one years later, that is, by 1952 the population of those that followed traditional religion had dropped to 21\% (Caldwell, J.C; Orubuloye, I.O and Caldwell, P.1991:230)

In a recent fieldwork in Ibadan, the author was told by a respondent that it would tantamount to several deliverance sessions if she had told her pastor that her family lineage worshipped/revered Esu. (Personal Communication, 2012) It was also noted that the new trend among some Yoruba is to give names as BB (Barrier Breaker), O Possible and Righteousness among other (Adekola, 2016).

Perhaps colonialism had the most devastating effect on Yoruba culture. Although some scholars argue that colonialism has introduced many 'positive' developments like western education, new professions, and occupations, new forms of socio-organization and so on but its burgeoning negative impact on Yoruba culture manifested in diverse manners. For instance, the first major blow was on Yoruba kinship system which hitherto had been the building block of the society. The idílé which was more or less a close knitted unit became fragmented and even at times torn apart. Akintoye (2010) extensively dwelled on this in the last chapter of his book on the history of the Yoruba people (429-467). A direct fall out of this is the fact that co-operation/ co-operative efforts exerted by family kin-units are no longer there. Similar to that is the fact that the training of children/wards is perhaps restricted to the 
members of the immediate family alone. The Yoruba adage that ẹì kan ní ń bímọ, gbogbo ayé ní ń wò ó which means the training of a child belongs to all in spite of having his biological parentage has given way to ẹni bímo ọràn ló ń pọn ọn that is who gives birth to a troublesome child must be ready to bear the consequences. Elsewhere the author has argued that individualism or the promotion of capitalism over common welfare has resulted in the increasing wave of violent crimes as hard drug peddling, arson, rape, murder, militancy and so on (Adekola, 1995).

Falola (2012) used Ibadan as a barometer of measuring the level of decadence, intolerance, misapplication of justice and the up-surge in crime that trailed the introduction of the colonial system in Yoruba land. For instance, land which during the pre-colonial Ibadan was regarded as God's gift became a goldmine while the authorities of the chiefs/Mogajis which were unquestionable was jettisoned for the "rod" of the colonial masters. Push came to shove as those considered not to be friendly to the colonial lords technically became the enemy of the state. In other words, the easiest way to have a criminal allegation leveled on an individual was perhaps to be seen as being against colonial administration. For instance, Balogun Akintola was accused of planning subversion just simply because he spoke against the introduction of the Town Council Administration while several Ibadan baále were thoroughly dressed down by European Residents for undermining the colonial authority at different times (Falola, 2012:362-399).

In pre-colonial Yoruba, the dispensation of justice was centered on fairness with little or no miscarriage of justice. Punishments were served without delay; this cannot be said of the prevailing judicial system in the Nigerian state (See Lawuyi, 2012). It however must be pointed out that there were pockets of extra-judicial killings and an unimaginable show of power by the authorities in pre-colonial Yoruba. Two examples will suffice here. Alaafin Ayibi beheaded one of his in-laws merely because his wife made a romantic statement concerning his manhood/small stature during a bath. The Yoruba have a saying for this ori yeye ni mogun, ti a se lo po that is, people often times suffer for offences they did not commit It was simply an attempt by the Alaafin to underscore his enormous powers (Adebayo, A.G. 1994). In the second example, one of Gaa's sons murdered a carrier in a bid to test his fancy of knowing if the man's neck had rather become so thick as not to allow him to carry a heavy load (Adebayo, A.G 1994). These instances were rather exemptions than the rule.

In terms of sexuality, there was no evidence of institutionalized sex in pre-colonial Yoruba while studies on sexuality in Ekiti, (Nigeria) Lesotho, Botswana, Tanzania and Zimbabwe have clearly shown that colonialism encouraged massive changes in sexuality, family life and sexual networking 
(Caldwell J, Orubuloye, I and Caldwell P, 1991). Today, in many parts of Yorubaland, bridal virginity appears to be rare. This is due to peer influences, infrastructures such as computers, internet facilities, television programming and so on. In fact, among today's youth bridal virginity as a tradition is considered archaic. ọmọ táyé ń bí, layé ń pọ̀n today's kids behaves in contemporary manners. This also applies to attitude to work. Traditionally, the Yoruba strongly belief in ișéloògùn iṣẹ literarily meaning hard work is the anti-dote to poverty but in modern times, the youths have practically changed this to omo tó bá mówó délé ni ìyá rẹ yóò yin (it is only the child who brings in money that would be praised by his/her mother)

Modernization which is essentially the aping of western culture has had more than a telling effect on Yoruba music, dance and language. The hip-hop culture has caught up with the Yoruba with little or no attention being paid to traditional music and dance steps.

In many Yoruba family homes these days the Yoruba language is no longer freely spoken. Some parents believe that their wards can only progress in life through queen English. The danger is with increasing tendency not to speak and write in Yoruba, the extinction of the language may be looming.

From our discussions so far, it is quite obvious that the Yoruba would have progressed along their own line but for the imposition of foreign ideas and cultures. They are a people that are very proud about their culture, dressing and their general way of life. This is reflected in one of their sayings, àifini peni, àìè̀ìyàn pènìàn, ní ń mú ará oko sán bàntẹ wộlú that is, it is out of total dis-respect for humanity and civilization that a bush man comes to town improperly clothed.

The kith and kin relationship would have greatly helped in propelling the Yoruba communities to foster a common front in tackling diverse difficulties ranging from domestic issues to environmental degradations.

The Yoruba could have also made further research into their dietary system with a view to improve on aspects inimical to the culture and to promote those that could have been acceptable to the outside world. But that was not meant to be with the ossification of foreign food crops and culinary systems. In terms of metal working, the importation of cheap iron led to the abandonment of iron working practices in Yorubaland and several parts of West Africa. Iron not only impacted political and ideological orders but also enhanced agriculture production which led to rapid population growth in Yorubaland (Adekola, 2011). The Yoruba iron technology also reflected the beauty of their inner minds which were represented in diverse works of arts such as sculptures, wood carvings and figurines. For example, in a Yoruba community of Esie, north central Yoruba land, close to a thousand soapstone figurines were 
found, the largest concentration of such in sub -Saharan Africa. (Adekola and Aleru 2010 \& 2011)

Despite of their engineering prowess, the Yoruba did not use the metallic currency such as gold and silver, their main trade currency was cowrie shells cyprae moneta. The use of cowries itself involved a complicated system of exchange based on the extensive use of the mathematical principles of addition, multiplication and subtraction (Adebayo, A.G 1994). All these were thrown to the dust bin following contacts with supposedly 'superior cultures'.

To the Yoruba the aping of western ideas and ideals has completely turned the adage, ajíse bí Ơyọ là ń rí, Òyọ kò ní șe bíi baba ẹnikan meaning the Oyo people are in the forefront of civilization, hence they do not copy others.

\section{Acknowledgement}

This piece is dedicated to the memory of a dear friend and a father, Pa Phillip Gbadegesin Ajekigbe who sadly passed on in February 2019. Ajekigbe, a solid field man, died few days after conducting archaeological fieldwork research with his students in KWASU less than 48 hours after marking his $70^{\text {th }}$ birthday. I sorely miss you; I know wherever you are, you are surely sending the triumphant saints 'into the bush'. May your gentle soul rest in peace. Thanks to the anonymous peer reviewer whose comments to this article were invaluable.

\section{Bibliography}

Adebayo, A.G. 1994. "Money, Credit and Banking in Pre-colonial Africa. The Yoruba Experience." Anthropos 89: 379-400.

Adekola, K.O.1992. "Traditional Palaces in Ibadan: A Case Study for C.R.M." An Unpublished B.Sc. Project of the Department of Archaeology \& Anthropology, University of Ibadan, Nigeria.

Adekola, K.O. 1995. "A Critical Appraisal of the Evolutionist and Diffusionist Theories." A Paper presented in the Department of Archaeology and Anthropology, University of Ibadan.

Adekola, K.O. 2011. "Dynamics of Metal Working Traditions in West Africa African Diaspora Archaeology." Network.www.diaspora.uiuc.edu/newsletter.html.

Adekola, K.O. 2011. "Towards the Preservation of Africa's Cultural Heritage” In Politics, Culture and Development in Nigeria. Akin Alao (ed.) Lagos: Centre for Black and African Arts and Civilization.

Adekola, K.O. \& J.O. Aleru, 2010\&2011. "Preliminary Report of Archaeology of Esie, North Central Yorubaland." West African Journal of Archaeology Vol 40.1\&2 and 41.1\&2: 89-107. 
Adekola, K.O. 2016. "Recent threats to Nigeria’s Cultural Identity and Patrimony." African Notes Vol 30.1\&2: 70-81.

Adekola, K.O. 2017. "Problem of Urbanization and Conservation of Cultural Landscapes in Africa: The Case of Ibadan, South Western Nigeria." South African Archaeological Bulletin 72. 205:46-59.

Akintoye, S.A. 2010. A History of the Yoruba People. Dakar: Amalion Publishing.

Atanda, J. A. 1980. An Introduction to Yoruba History. Ibadan: Ibadan University Press.

Caldwell, J.C, Orubuloye, I.O. and P. Caldwell. 1991. "The Destabilization of the Traditional Yoruba Sexual System." Population and Development Review 17.2: 229-262.

Eltis, D. 1990. "Welfare Trends among the Yoruba: The Anthropometric Evidence." Journal of Economic History 50.3: 521-540.

Falola, T. 2012. Ibadan: Foundation Growth and Change 1830-1960. Ibadan: Bookcraft.

Folorunso, C.A. 1998. “The History and Anthropology of Labour Mobilization for Agricultural Production among the Yoruba." West African Journal of Archaeology 28.2: 65-80.

Frobenius, L. 1913 The Voice of Africa 1. New York: Benjamin Blom.

Johnson, S. 1921. The History of the Yorubas. London: Lowe \& Bryclone.

Law, R.C.1973. "The Heritage of Odùduwà: Traditional History and Political Propaganda among the Yoruba." Journal of African History XIV.2: 207-222.

Law, R. 1984. "How Truly is Our Traditional History? The Case of Samuel Johnson and the Recording of Yoruba Oral Tradition." History of Africa. 11: 195-221.

Lawuyi, O.B. 2012. Sceptical Public, Public Managers and the Decline of Moral Public on Nigeria's Public Space. Inaugural Lecture 2011/2012, University of Ibadan.

Mabogunje, A.I. 1962. Yoruba Towns. Ibadan: Ibadan University Press

Mabogunje, A. \& J.D. Omer-Cooper. 1971. Owu in Yoruba History. Ibadan: Ibadan University Press.

Ogundiran, A. 2011. "Crises of Culture and Consciousness in the Post Colony: What is the future for Nigeria." Keynote Address at the Conference in Honour of Uli Beier, Institute of African Studies, University of Ibadan, Nov 28-30.

Ojo, G.J.A. 1966. Yoruba Culture. Ile-Ife: University of Ife Press Ojo, O. 1977. The Climate of West Africa. Ibadan: University Press Ibadan Vayda, P.A. 1987. "Explaining What People Eat." Human Ecology: An Inter-disciplinary Journal. 15.4: 493-510. 
Yoruba Traditions in the midst of Foreign Influences, A Critical Evaluation 111

Sowunmi, M. A. 1999. “The Significance of the Oil Palm (Elaeis guineensis) in the late Holocene Environments of West and West Central Africa further Consideration." Journal of Vegetation History and Archaeobotany. 8: 199-210. 